\title{
STUDIES ON PHYTOPLANKTON DIVERSITY OF CHANDRASAROVAR POND OF JHALAWAR (RAJASTHAN)
}

\author{
Arjumand Qureshi ${ }^{1}$, Dr. Prahlad Dube ${ }^{2}$ \\ ${ }^{1,2}$ Government PG College, Jhalawar, Rajasthan, India
}

Article DOI: https://doi.org/10.36713/epra9394

DOI No: 10.36713/epra9394

\begin{abstract}
The present study was to understand the diversity and distribution pattern of microalgae in fresh water system represented by an open artificial pond. A total of 100 species of phytoplanktons were indentified from different groups in Chandrasarovar pond of Jhalawar, Rajasthan. Among the identified phytoplankton species Cyanophyceae (39\%) formed the dominant group, followed by Chlorophyceae (34\%) Bacillariophyceae (23\%) and Euglenophyceae (4\%). The fluctuations in the physicochemical parameters like $\mathrm{pH}$, temperature, $\mathrm{EC}, \mathrm{DO}, \mathrm{BOD}, \mathrm{COD}$, turbidity, alkalinity, hardness, nitrate, silicate, phosphate and were also been monitored. The result provides a primary documentation of the phytoplankton community and its diversity and basic understanding of hydrological variables in the Chandrasarovar pond .
\end{abstract}

KEYWORDS: Pond, Chandrasarovar, Jhalawar, Rajasthan, Phytoplanktons, Hydrology

\section{INTRODUCTION}

Ponds are generally small natural or artificial, shallow, confined bodies of standing water usually have a muddy or silty bottom that provides habitat and food for many species. 


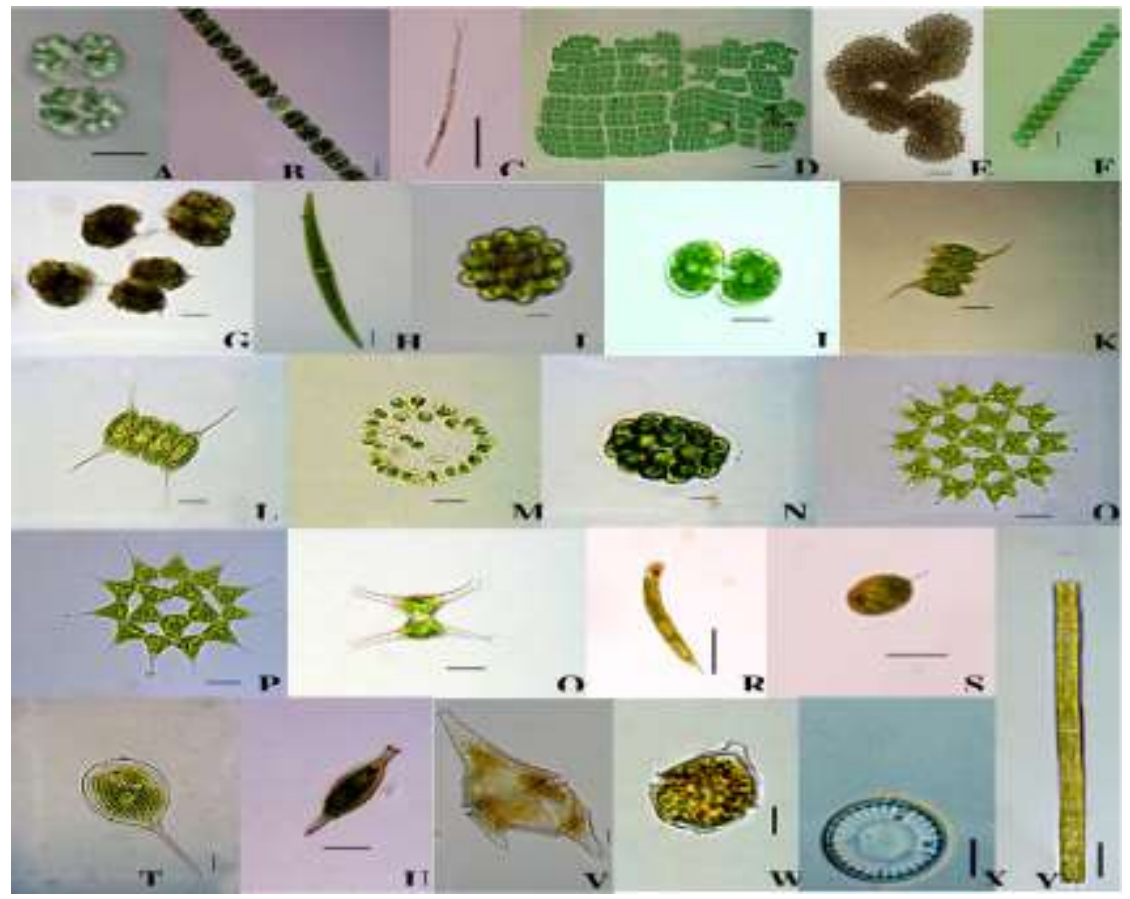

\section{Phytoplankton Diversity}

It is too small for wave action and too shallow for major temperature differences from top to bottom. These freshwater communities are extremely sensitive to environmental variations. Phytoplanktons are the microscopic free floating algal communities of water bodies and productivity of an aquatic system is directly related to diversity of phytoplankton. The phytoplanktonic study is a very useful tool for the assessment of water quality and productivity of any type of water body and also contributes to understanding of lentic water bodies . Phytoplankton includes several thousands of microalgae belonged to Chlorophyta (green algae), Cyanophyta (blue green algae), Bacillariophyta (diatoms), Euglenophyta (pigmented flagellate or phytoflagellated) etc. They respond quickly to environmental changes and are used to assess the ecological status of water body. They are used for assessing the degree of pollution or serve as bioindicators of water quality. Phytoplankton has been used recently as an indicator to observe and understand changes in the ecosystem because it seems to be strongly influenced by climatic features. Phytoplankton diversity and succession in small manmade ponds are largely ignored. In the present study an attempt has been made to assess the diversity of phytoplankton and their distribution and fluctuations in the hydrological variables in Chandrasarovar pond of Jhalawar.[1,2]

\section{METHODOLOGY}

The study was carried out and Chandrasarovar pond in Jhalawar was selected in Rajasthan. [3,4]Phytolankton samples were collected by filtering pond water through plankton net with $25 \mu \mathrm{m}$ mesh size. The filtrate was immediately preserved in $4 \%$ formaldehyde. The phytoplankton samples were observed thoroughly under microscope and have been identified with the help of standard literature and also analyzed few physico-chemical parameters as per standard procedures . [5,6] 


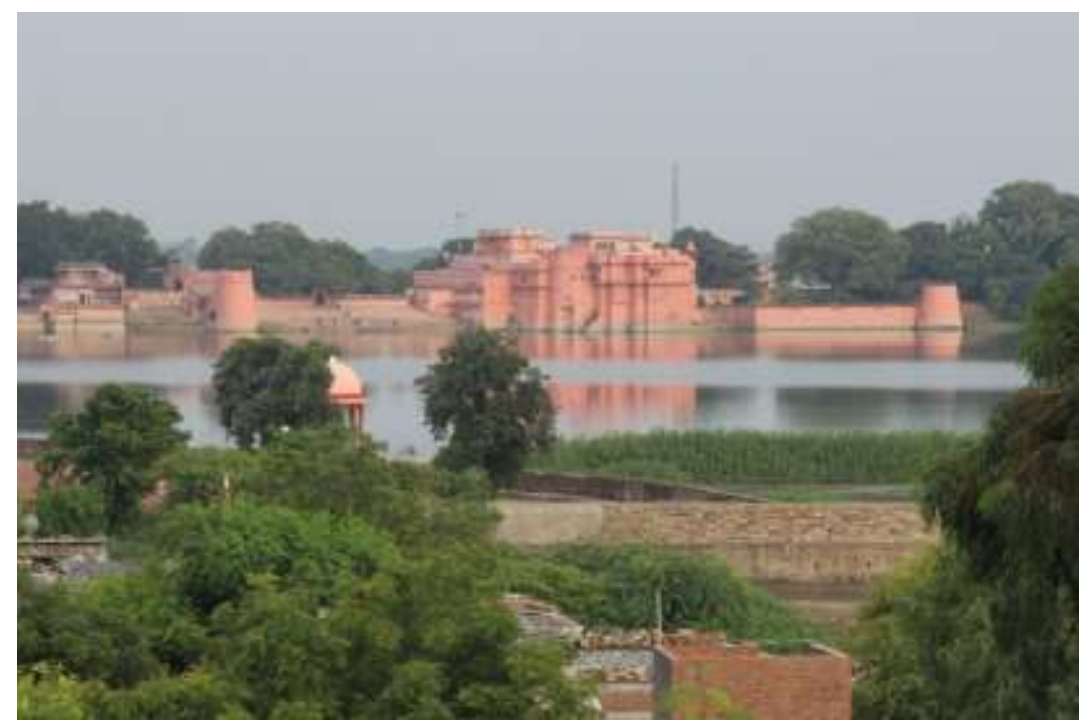

\section{Jhalawar in Rajasthan}

\section{RESULTS}

Phytoplankton in Chandrasarovar pond was represented by four classes of algae viz. Chlorophyceae, Cyanophycae, Bacillariophyceae and Euglenophycae. In the selected pond 100 species of phytoplankton members were identified among these Cyanophyceae includes 39 species followed by
Cholorophyceae 34 species, Bacillariophyceae recorded 23 species and Euglenophyceae reported 4 species. The percentage wise contribution of phytoplankton groups were studied. Diversity of phytoplankton during the study period was investigated. [7,8]

\section{DISCUSSION}

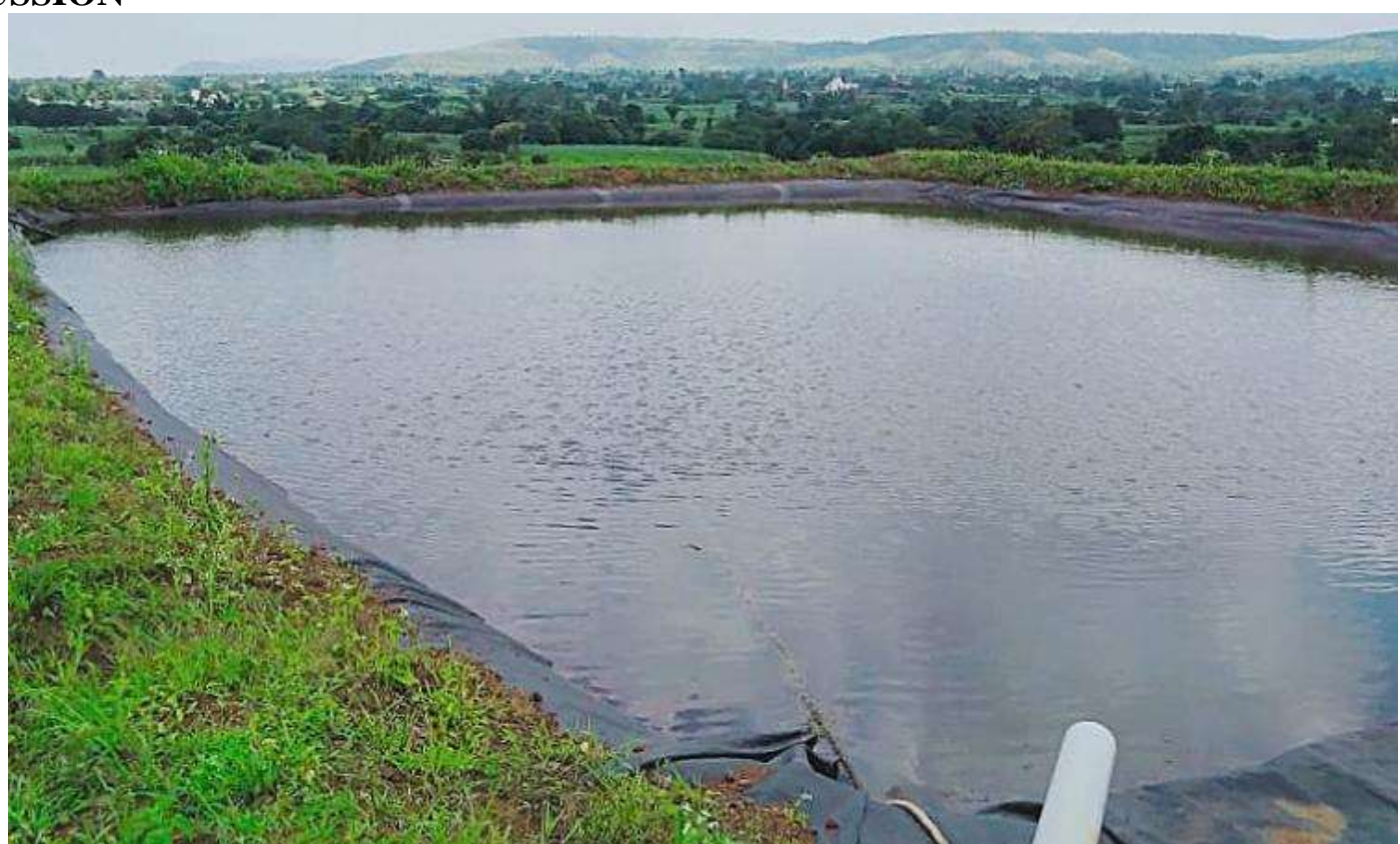

\section{Chandrasarovar Pond}

Cyanophycean members contributed maximum diversity in the Chandrasarovar pond and were the most dominant class, it contributed about $39 \%$ of the total phytoplankton population . Genus like Chroococcus, Microcystis, Oscillatoria, Merismopedia, Anabaena, Nostoc, Aphanocapsa, Eucapsis, Arthrospira, Phormidium, Rivularia, Lyngbya, 
Anabaenopsis, Scytonema, Synechococcus, Gomphosphaeria, Aphanothece and Spirulina were recorded. Chlorophyceae was the most significant group of phytoplankton contributing $34 \%$ from the total phytoplankton population. Cholorophyceaen diversity was highest. [9,10] This class was represented by Ankistrodesmus, Characium, Chlorella, Chlorococcum, Cladophora, Closterium, Cosmarium, Crucigenia, Euastrum, Gleocystis, Hydrodictyon, Netrium, Oedogonium, Oocystis, Pediastrum \& Scenedesmus. In the case of Bacillariophyceae $23 \%$ of phtoplanktons were in this group. Among the diatoms Achnanthes, Amphora, Cyclotella, Cymbella, Fragilaria, Gomphonema, Gyrosigma, Melosira, Navicula, Nitzschia, Pinnularia, Suriella, Synedra and Tabellaria were found. Euglenophyceae contributed minimum of $4 \%$ phytoplankton. Throughout the study this group was mostly represented by Euglena and Phacus.[11,12]
Temperature recorded in the chandrasarovar pond water was $28.81 \pm 1.03^{\circ} \mathrm{C}$, where as the $\mathrm{pH}$ of water was found almost neutral during the study period (7.47 \pm 0.61 ). Electric conductivity recorded from the cemented pond was $57.36 \pm 4.02 \mu \mathrm{m}$ hos $/ \mathrm{cm}$. Total hardness and total alkalinity recorded was $9.83 \pm 3.45$ $\mathrm{mg} / \mathrm{l}$ and $48.36 \pm 9.43 \mathrm{mg} / \mathrm{l}$. In present study DO, BOD and COD values were recorded as $6.63 \pm 1.44 \mathrm{mg} / \mathrm{l}$, $3.78 \pm 1.48 \mathrm{mg} / 1$ and $4.38 \pm 1.56 \mathrm{mg} / 1$ respectively. Nutrients like phosphate, silicate and nitrate were found correspondingly in $4.87 \pm 1.59 \mathrm{mg} / 1,2.94 \pm 1.68 \mathrm{mg} / \mathrm{l}$ and $5.25 \pm 1.97 \mathrm{mg} / 1[13,14]$

\section{DISCUSSION}

Phytoplankton are sensitive to the environmental changes and their distribution varies considerably with respect to seasons, water quality and nutrient concentrations .

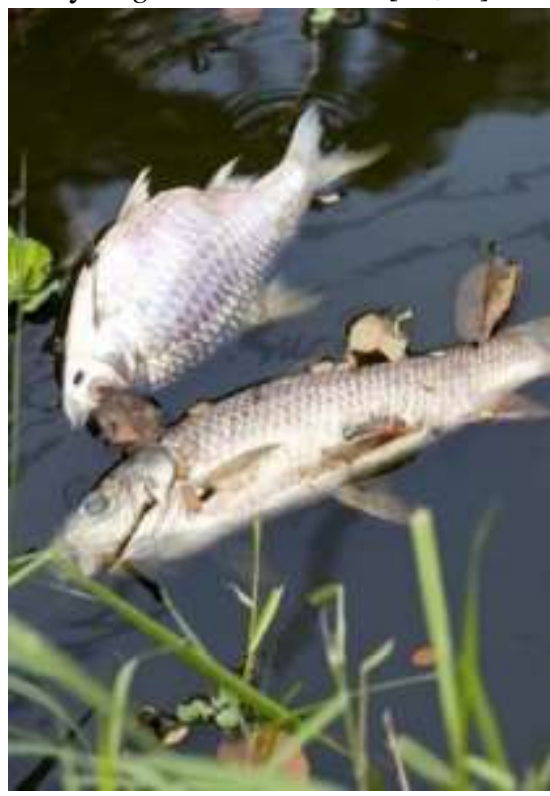

Fish in the Chandrasarovar pond

Planktonic communities are influenced by the prevailing physico- chemical parameters and these determine their abundance, occurrence and seasonal variations . In the present investigation, 4 group of algae viz. Chlorophyta, Cyanophyta, Bacillariophyta and Euglenophyta were identified. In present study algal taxa Cyanophyceae and Chlorophyceae dominated as compared to other groups of algae. The seasonally distribution of algal diversity shows dominance nature as Cyanophyceae > Chlorophyceae > Bacillariophyceae > Euglenophyceae. Cyanophyceae group contributed $39 \%$ of total phytoplankton which

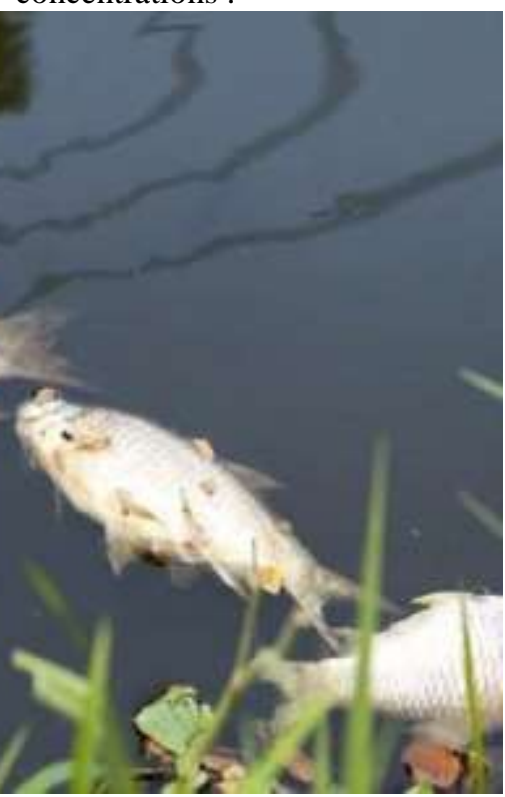

suggested that higher value of nutrients favored the growth of Cyanophyceae. Cyanophyceaen members. Many workers have reported blue green algae as a dominant group during these periods . The dominant nature of Cyanophycean members are the characteristic feature of eutrophic environment which have high concentrations of nutrient especially phosphate and nitrate . In the present study maximum population of blue green algae was observed . [15]The occurrence of rich algal flora results generally at the place where there are high levels of nutrients, together with favorable environmental conditions . 


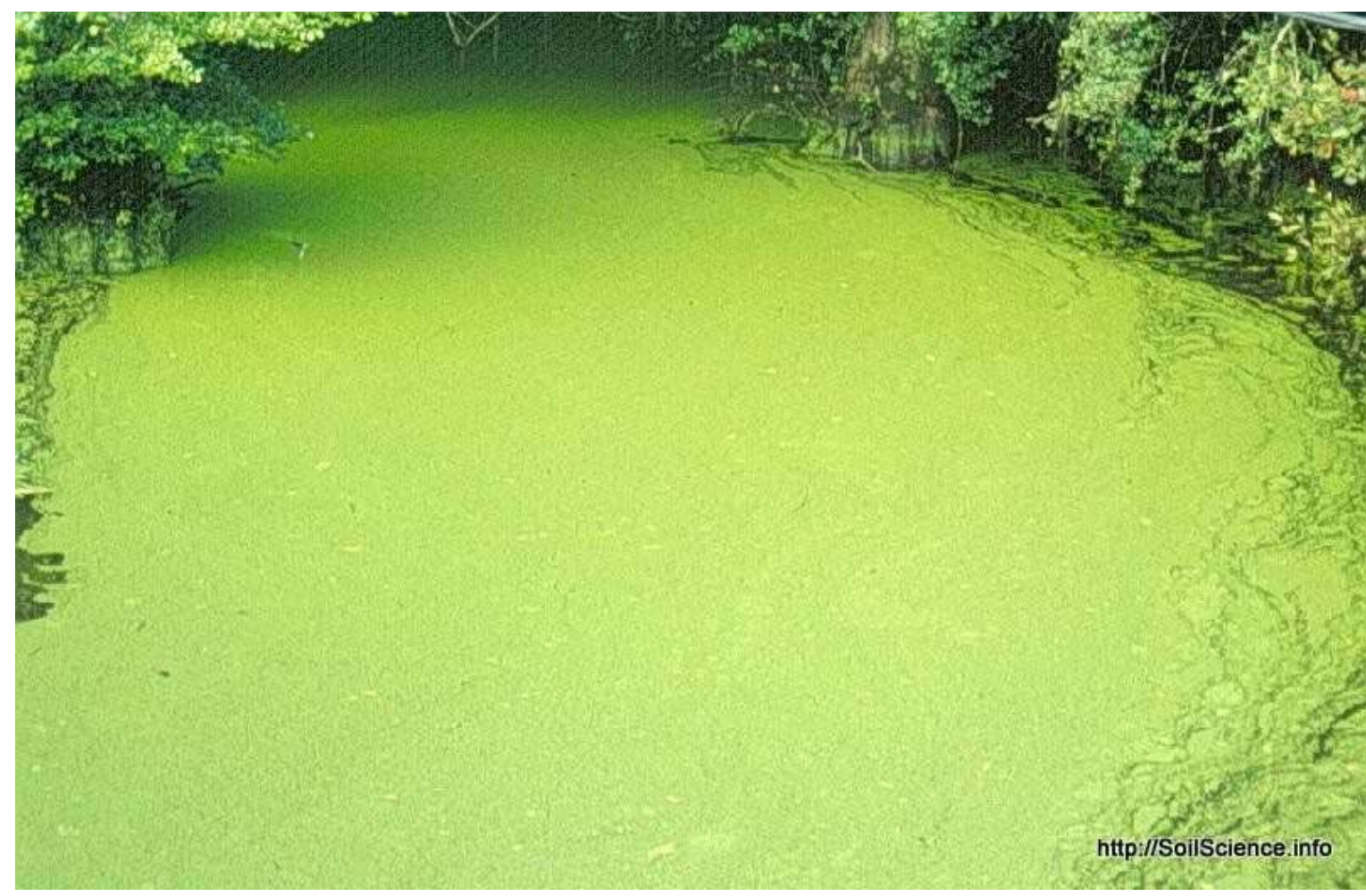

\section{Dominance of chlorophyceae in the pond}

Chlorophyceae group dominate the water that is rich in nutrients such as nitrate and phosphate. The regular supply of nitrate encouraged the growth of diatoms. The presence of phosphate, nitrate, silicate and total hardness promoted the growth of diatoms. Euglenophyceae was reported maximum during the months were temperature and nitrate values were noted higher. Previous studies on freshwater environment showed that higher temperature and nitrate concentration favours the growth of euglenoids. The temperature above $25^{\circ} \mathrm{C}$ was good for the growth of Euglenophyceae. The high temperature, chloride, TDS, and BOD might have played an important role in growth and development of Euglenophyceae. In the present study the values of physico-chemical parameters fluctuates greatly during different months. This may be due to various physico-chemical factors which are modifying the diversity of phytoplankton. The physico-chemical conditions had a direct relationship on phytoplankton diversity in aquatic ecosystem. The $\mathrm{pH}$, dissolved oxygen, alkalinity and dissolved nutrients are important for phytoplankton production. It was observed that DO possess an indirect relation with temperature. The solubility of oxygen, or its ability to dissolve in water, decreases as the water's temperature increase. EC is a numerical expression of the ability of an aqueous solution to carry electric current. EC is an indication of extent of salinity in the pond water samples. The phytoplankton diversity is largely influenced by interaction of a number of physico-chemical and biological factors acting simultaneously. The maintenance of a healthy aquatic ecosystem depends on physico- chemical and biological diversity of the ecosystem. From the present observation it is difficult to point out any single factor which is responsible for the fluctuations and abundance in plankton community. The present study reveals that variation in the abundance of plankton is explained with abiotic factors. Thus it may be noted that the density of phytoplankton is dependent on different abiotic factors either directly or indirectly.[16] 


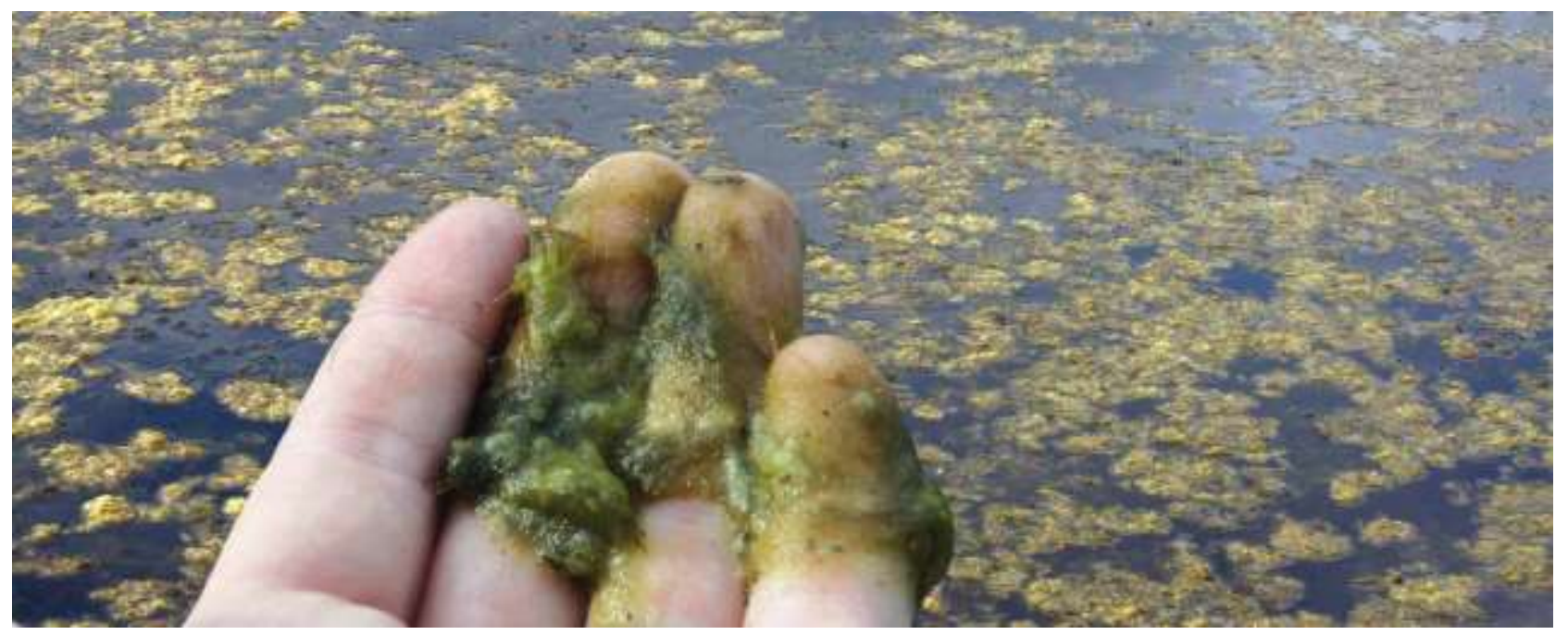

Phytoplankton diversity in Chandrasarovar pond

\section{CONCLUSION}

The present study provides an insight into the distribution, abundance, diversity and ecology of phytoplankton in Chandrasarovar pond, Jhalawar, Rajasthan. From the results, it is evident that the ecological conditions of pond support a rich diversity of algal flora. The pond had a diversified group of phytoplankton dominated by Cyanophyceae members followed by Chlorophyceae, Bacillariophyceae, and Eugleanophyceae. Results indicated that the values of physico-chemical parameters were responsible for the diverse group of phytoplankton in Chandrasarovar pond.[17]

\section{REFERENCES}

1. Anand, N., 1998. Indian freshwater microalgae. Bishen Singh Manendra-Palsingh, Dehradun. pp.5-88.

2. Ansari Ekhalak, Mohini Gadhia and Ujjania, N.C.,2015. Phytoplankton diversity and water quality assessment of ONGC pond, Hazira. IJRES 1(1): 1-15.

3. APHA, 2005. Standard methods for the examination of water and waste water. AWWA, WPCE, New York, 21 st edition.

4. Ashok Aswathy J.A., Dr. J.K. Reshma, Anu Mathew and Dr. Rajesh Raghunath, 2015. Effect of water quality on phytoplankton abundance in selected ponds of Athiyannoor Block Panchayat, Kerala. Jour. Sci. Res. A. Sci., 1 (2): 91-100.

5. Bais, V. S. and Agarwal, N. C., 1990. Seasonal variations of nitrogen contents in the sediment and water of the Sagar lake. Bull. Environ. Sci., 8: 21 - 24.

6. Desikachary, T. V. 1959. Cyanophyta. Indian Council of Agriculture Research, New Delhi.

7. Devi Anita, U., and Singara Charya, M.A., 2007. Phytoplankton in lower Manair dam and Kakatica canal, Karimnager. Nat. Environ. Pollu. Tech. 6(4): 643-648.
8. Devika, R., A. Rajendran, and Selvapathy, P., 2006. Variation studies on the physicochemical and biological characteristics at different depths in model waste stabilization tank. Pollut. Res., 24: 771-774.

9. Fritsch, F.E., 1935. The Structure and Reproduction of the Algae Vol I. Published by Cambridge University Press London.

10. Ganai, A.H., S. Parveen, Asif A. Khan and Maryam, H., 2010. Phytoplankton diversity at Watlab Ghat in Wular lake, Kashmir. J. Eco. Nat. Environ. 2(8): 140146.

11. Gopinath Priya, T. and Ajit Kumar, K.G., 2014. A study on the physico-chemical parameters and diversity of phytoplankton in Vellayani lake,Thiruvananthapuram, Kerala, India. Journal of Aquatic Biology and Fisheries, 2: 489 -492.

12. Harikrishnan, K. Sabu, G. Sanil, M. Paul, M. Satish and Das, M.R., 1999. A study on the distribution and ecology of phytoplankton in the Kultanad wetland ecosystem, Kerala. Pollut. Res., 18: 261- 269.

13. Hudder, B.D., 1995. Hydrobiological studies in lentic freshwater bodies of Hubli Ph.D. Thesis. Submitted to Karnataka University, Dharwad, pp. 267.

14. Hujare Milind, S., 2008. Seasonal variation of phytoplankton in the freshwater tank of Talsande, Maharastra. Nat. Envir. And Pollu. Tech. 7(1): 147150.

15. Jasprica, N., H. Dubravika, C. Marina, and Rimac, A., 2006. A preliminary investigation of phytoplankton of karstic pond (Dugi otok Island, Croatia). Acta. Bot. Croat., 65(2): 181-190.

16. Jayabhaye, U.M., 2010. Studies on Phytoplankton diversity in Sawana Dam, Maharastra, India. Samiksha Aur Mulyankan., 11(11-12): 40-42.

17. Joseph Jiji, 2012. Studies on the Cyanobacterial diversity from selected freshwater environment and its application in biotechnology. Ph.D. Thesis. Submitted to M.S. University, Tirunelveli. 